\title{
THE SOCIAL ASSISTANCE SYSTEM IN BULGARIA
}

\section{Venelin Terziev ${ }^{1}$, Margarita Bogdanova ${ }^{2}$, Dimitar Kanev ${ }^{3}$, Marin Georgiev ${ }^{4}$, Simeon Simeonov ${ }^{5}$}

${ }^{1}$ Full Member of the Russian Academy of Natural History, Professor, Eng., D.Sc. (National Security), D.Sc. (Economics), D.Sc. (Social Activities), Ph.D., Russian Academy of Natural History, Moscow, Russia, Vasil Levski National Military University, Veliko Tarnovo, Bulgaria University of

Rousse, Rousse, Bulgaria, terziev@skmat.com

${ }^{2}$ Professor, Ph.D., Tsenov Academy of Economics - Svishtov, Bulgaria,

m.bogdanova@uni-svishtov.bg

${ }^{3}$ Professor, D.Sc. (Ec.), Ph.D.Nikola Vaptsarov Naval Academy, Varna, Bulgaria, kanev@dkanev.com

${ }^{4}$ Ph.D., National Military University, Veliko Tarnovo, Bulgaria, clementon@abv.bg

${ }^{5}$ Ph.D., University Hospital "Kaneff" - Rousse, Bulgaria, sansiood@abv.bg

\begin{abstract}
Social policy as a set of principles, legal norms, activities and institutions, aimed at creating conditions that ensure the quality of life of the citizens of a country, is an expression of the social relations between the state and its citizens. Social policy determines safety (social, health, economic) and security of the individuals in society.
\end{abstract}

Keywords: social assistance, social protection, social policy.

\section{INTRODUCTION}

Social assistance is a form of social security in which funds are made available to persons who are in need and are not in a position to have another legitimate reason to acquire such. Social payments are made in the form of benefits that can be cash or in kind. They guarantee the existence of people in distress in the present.

The social assistance is carried out according to a Law and Regulations of the Council of Ministers. The defined main objective is to help citizens who, without the benefits, cannot meet their basic life needs, as well as to develop and strengthen public solidarity in difficult life situations. Social assistance is performed in a way that preserves the dignity of citizens.

According to the normative documents, Bulgarian citizens are obliged to take care of their basic life needs. The right of social assistance is granted to Bulgarian citizens, families and cohabitants who, due to health, age, social and other reasons beyond their control, cannot, by themselves or with the benefits they receive satisfy their basic living needs. Through the social assistance these citizens complement their own resources (Petkova, 2019b, Petkova - Georgieva, 2018e).

In the broad sense of the term social assistance also refers to the provision of services in the form of food provision, cleaning of homes, medical and transport services for the disabled and the elderly, living alone. 
This also includes the accommodation and servicing of adults and disabled people of different age groups in social institutions.

The right to social assistance also applies to refugees who are legally residing in the country if this is stipulated in a law or in an international treaty to which the Republic of Bulgaria is a party. The receipt of monthly social benefits is linked to the provision of socially useful work. This does not apply in the case of maternity or when the age or health status of the person does not allow this (Terziev, Nichev, Simeonov, 2018-b).

No discrimination, privileges or limitations on grounds of nationality, race, ethnic or political affiliation, sex, age, religious belief, and social status shall be permitted during the implementation of social assistance (Terziev, Banabakova, Georgiev, 2018c-d).

\section{CHARACTERISTICS OF THE SOCIAL ASSISTANCE SYSTEM}

In view of the commitments made by our country related to our membership in the EU (European Union), a new concept of social protection of Bulgarian citizens was adopted. According to it, every Bulgarian citizen is responsible for his/her individual well-being, and the state is committed to creating prerequisites for increasing employment, reducing poverty and overcoming social exclusion in a still unfavourable economic environment. In the field of social activities is taken a differentiated approach, which aims to provide effective support to those who really need it. Attention is focused on each person with his / her problems and needs. The guidelines for the development of social activities are determined by adopting an active approach in this area. The development of social assistance cannot be reviewed in isolation from the processes taking place in other parts of the social protection system (Petkova - Georgieva, 2017; Petkova - Georgieva, 2016).

\section{Social benefits}

Historically, at the beginning of the transition, the social assistance system in Bulgaria is characterized by a complex and ineffective structure of benefis and services. It developed on the basis of a comprehensive social security system, characterized by a low retirement age, multiple schemes for benefits of a non-social security nature. At the same time, a number of new income support schemes such as monthly support, free medicine provision, child benefit for unemployed parents, and energy aids have been created. There is an unconditional need for comprehensive and profound restructuring, which is delayed due to the lack of economic stability, political consensus and broad public support. The implemented social assistance policy faces the need to influence the consequences of the performed economic policy (Petkova - Georgieva, Yanakieva, 2018f; Karadzhova, Petkova - Georgieva, 2016a). This also predetermines her passive character. It is only after 1997 that the necessary measures have been taken to modernize the system. Efforts are directed towards building sustainable support schemes that are aimed at minimum levels of social benefits, focusing, complementarity, avoiding duplication and removing opportunities for irregular claims.

The mechanism for support schemes currently in place is linked to the maintenance of the low income line of the differentiated minimum income and the existence of multiple restrictive criteria that reduce potential clients to the circle of the long-term unemployed and marginalized population groups. After 1992 the Base Minimum Income (BMI) has been maintained well below the minimum wage, unemployment benefits and even the social pension. Due to this fact, families with more than one permanent source of income are left out of the protected income line. This has caused problems such as:

- Increase of assisted persons in working age. Not only did the number of unemployed persons in working age who were receiving social benefits increase but also the share of long-term unemployed who lost their working habits, qualification and motivation to work. In December 2002, the long-term unemployed are 358.4 thousand or $65.8 \%$ of the total number of unemployed, and the assisted unemployed persons in working age are over 180 thousand, with more than half being up to 30 years of age (2019).

- In the developed sustainable clientele, $80 \%$ of the assisted persons have primary and no education, and $29 \%$ are illiterate. The multiple group of unemployed persons receiving social benefits under the terms and conditions of the Social Assistance Act consists mainly of persons who do not work and live on social support (for them the social assistance is a way of life); persons, who work in the informal economy without a contract of employment, but their income cannot be established; persons who do not work due to taking care for seriously ill relatives.

- Low level of monthly benefits. It is not only low but also insufficient. Those entitled to it cannot live only from social assistance. Their reintegration into the labour market is not particularly realistic in view of their educational and qualification level. The ration minimum wage - social assistance is such that it stimulates their inclusion in the informal economy. 
- Difficulties in valuing incomes from the natural economy. When a social worker finds significant income in kind, he may refuse assistance based on property criteria - land, farm equipment, animals, household items, craft tools. He assesses the extent to which they are an indicator of the standard of living of the assisted persons. This practice creates prerequisites for subjectivism and inequality of the recipients.

This has required measures to be taken in the direction of:

- Increase of the Differentiated Minimum Income (DMI) for certain categories of persons. The introduced changes in the coefficients help to focus financial aid on those who have the lowest income and need most support from the state. These are lonely living elderly people, people with disabilities, and single parents who by themselves raise children up to 3 years of age.

- Provision of employment to long-term unemployed persons. The implementation of the National Program "From Social Assistance to Employment" involves 264 municipalities and includes more than 82,000 unemployed people (2019a). The aim is to provide employment and social integration through job creation in community-based and state-owned activities and provision of social services. Special attention is paid to the long-term unemployed who take care for relatives with permanent disabilities. The "Personal Assistant" project aims at alleviating the social situation of people whose relatives need constant care. The "Home Assistant" and "Social Assistant" programs are similarly targeted.

- Better coordination between territorial structures of social assistance, employment, tax administration, municipalities to curb abuse of social benefits.

- Strengthening control at all levels of the assistance system.

- Building a unified information system aimed at better coordination, accountability and forecasting of assistance needs.

- Implementation of social work with assisted persons.

Looking for greater effectiveness of the social poll. It is detailed, with the range of questions expanded. Social worker's responsibility is growing. The nature of his duties requires a specific qualification. $\mathrm{He}$ is expected not only to motivate his proposal to grant/deny social assistance but also to draw up an individual plan to improve the quality of life of the assisted (inclusion in employment and qualification and requalification programs, provision of social services, assistance and number of institutions). A new model of work is trending. Its introduction is related to objective and subjective difficulties. On the one hand, a lack of traditions, a lack of concomitant social services, an established bureaucratic manner of work, on the other hand, a lack of experience and qualifications among workers, prejudices to the clients, overworking of social workers.

\section{Social services}

There are serious problems in the social assistance system, which are not just related to a shortage of funds.

Large-scale spot checks were carried out in 2000 to test the system. Serious shortcomings are found related to employee training and the professional level of the social assistance system. Especially difficult is the problem with social services institutions. The organization of work there as well as staffing are far from the normal standards and requirements for work in such establishments. This affects the quality of services. They are at a very low level. Instances of complaints and signals, as well as intolerable cases are not rare in some establishments, group rape of a girl from Social educational-professional institution (SEPI) Kachulka; beating a child in the Home for children and adolescents with mental retardation - Strazha, as a result of which the child stays in a corset for one month in a hospital; a drowned youth in SEPI Glavinitsa and many others which are evidence of the irresponsible and callous attitude towards the residents in the institutions (Bozhilova, 2006).

As of the end of 2005, there are 187 specialized social care institutions registered in Bulgaria with 13900 people (2019) in them. The largest relative share is the one of old people $(31.5 \%)$ and adults with mental disabilities (32.8\%).

Much of the specialized institutions for social services are located outside the populated areas. Their material base is amortized. Municipalities face difficulties in securing their maintenance. There is no social work with the people in the institutions. There are no conditions for civil control over the observation of the human rights.

The most well-developed form of social service in the usual home environment is the Home Social Patronage. This service is available in most of the municipalities. At the end of 2003 , its users were 28,875 . 
The relative share of customers of other services in the community is Only $4.6 \%$. The most rapidly developing service is the day centre for children or young people with mental disabilities. For the past year, 3 new centres have been created. The reasons for the underdevelopment of social services in the community may be due to the lack of financial resources, the absence of a tradition of offering and using such services.

In the sphere of social services the following groups of problems emerge:

- Problems with customer service. Due to lack of financial resources and changes in the health care system, the caregiving, hygiene and living conditions and medical services are deteriorated. Individual work with the clients is insufficient. No work with families and their relatives;

- Problems of employees in specialized institutions and social services in the community. Employees usually do not have enough practical skills for social work. They often lack the necessary skills and qualifications because of the remoteness of specialized institutions from large settlements. There are no opportunities for professional growth. Working and pay conditions are not particularly good;

- Problems, related to equipment and financial support. The material base is amortized. Funds for repair and maintenance are needed. The contingents they work with, are costly. The values at which the budget is formed are extremely low, resulting in a deficiency in implementation (For example, planned medicines, medical and dental care are very limited, although the Agency for Social Assistance (ASA) provides recommendations for 24-hour medical surveillance. No positions on the pay-roll are foreseen for rehabilitators, psychologists, and other professionals professionally related to the clients. Their inclusion would improve the quality of the service.).

- Problems caused by changes in management and funding of social services. The schemes introduced give rise to some tension between the territorial divisions of the ASA and the municipal administration related to:

- Informing potential clients about social services on the territory of the municipality. Stakeholders in municipalities have difficulty in obtaining complex information;

- Terms and conditions for the performance of the services. Decentralization in the sphere of social services requires them to be performed by the provider (Art. 40 of the RISAA). Municipalities have difficulty in doing so. Methodological guidance from the ASA is delayed;

- Coordination between the municipality and the territorial divisions of the ASA in relation to the activities, which are state's responsibility. The most frequent difficulties arise in taking into account the vacancies in the specialized institutions on the territory of the municipality, accommodation, relocation and discharging from them.

Efforts are made to modernize social services by adapting Western models to Bulgarian conditions. In view of this, priorities have been identified, related to increasing the relative share, volume and nomenclature of the services offered in the community; expanding the participation of NGOs in the system of social service providers; standardization and valuation of all types and forms of social services; social work with clients; improving living conditions in specialized institutions.

The main principles in the provision of social services are as follows:

- Timeliness, reasonable sufficiency, social justice;

- Help for self-help and mutual assistance;

- Freedom of choice, equality, awareness;

- Professional offering and confidentiality.

The analysis of the state of the social assistance system in Bulgaria, with an emphasis on the dynamically changing needs of the population, on the one hand, and the forthcoming membership of our country in the European Union (Petkova - Georgieva, Tasheva, 2018g), on the other hand, allows us to make the following comments:

- Territorial distribution - the system has a structure that combines a centralized approach to social assistance programs and decentralized approach for provision of the social services. Territorial units and divisions were established. Changes in social services are at an early stage. Municipalities are in the process of building social complexes, including offering social services in line with local needs.

- Facilities - the buildings used by the ASA divisions are for the most part adapted to that purpose. Some of the buildings need reconstruction, others - repair and maintenance. The furnishings are old. There is not 
enough computer equipment. Some of the units do not have their own transport. It is particularly necessary in small rural and mountain communities, where the work of the social worker is hampered by the remoteness of the settlements in his area. The specialized institutions for social services are located in the periphery of the populated areas. The vast majority of them are in villages, far from the municipal centres.

- Scope of the indigent - a priority in the social assistance system are the following categories of risk groups: families in which, for reasons of household, health or social character, the raised children are at risk; lone parents; people with permanent disabilities and their families; lonely elderly people; long-term unemployed.

- Technological variant of reform - a variant oriented towards the scheme "minimum social transfers, developed social services" is adopted, characterized by:

- Targeted social assistance. Targeted cash benefits have been introduced for people with incomes below a certain minimum. Targeting is done by checking the funds. Aid is simplified;

- Incentives to work. To reduce reliance on social benefits, incentives to work such as referrals to employment programs, maintaining low levels of aid are used;

- Child benefits. The universal nature of child support is limited. These benefits are granted on the basis of an income check. They are designed to promote the inclusion of children in the education system. Their size is fixed and does not depend on the number of children in the family and the status of the mother;

- Benefits in kind. The effectiveness of this kind of aid is increased by improving the forms of targeted support;

- Social services. Priority is given to the development of social services in the community. The municipalities are encouraged to develop strategies for the development of social services on their territory. The input stream to the specialized institutions is restricted. Efforts are aimed at improving the quality of life of those staying in them. NGOs are encouraged to provide social services. A new nomenclature of social services, which includes one not-known in the Bulgarian practice has been established. There is some delay in the preparation of adequate legislation on social services. Still cannot be talked about a market for personal social services.

- Financing and management of social assistance. Since 1997, a new regulatory base has been developed. It is based on the Social Assistance Act (1998). Local authorities gain greater autonomy in administering social services. The state ensures the functioning of the monitoring and regulation mechanisms in this area and manages the social assistance programs. There are still problems in providing adequate funding.

- Future development guidelines - determined by the active approach adopted and associated with:

- A clear outline of the beneficiaries of the system;

- A clear distinction between the needs for cash support and the assistance with social services in the form of social work and social care;

- Transforming social assistance to help provide employment for all people in good health and working age.

- Better addressing and targeting of social payments to people with the lowest income and most needing support by improving access mechanisms and ensuring that they are used as intended; introducing new forms of targeted support.

- Development of social services aimed at overcoming social exclusion. Creating community-based care standards and specialized institutions, as well as quality control criteria.

- Privatization and deinstitutionalization of social services. Involving municipalities and various charities and business organizations in providing social services. Clear distinction between the functions and duties of the various entities.

- Improving the structure of management and financing of social assistance. Finding the optimal degree of decentralization. Establishment of normative conditions for the denationalisation and deinstitutionalization of social services as well as the professional qualification requirements for the employees in the social assistance system. Improving the administrative capacity of the system, harmonizing its structures with the European legislation and improving the coordination between its units. 


\section{CONCLUSION}

The development of the social policy in different countries is closely linked to the natural, economic, cultural, ethnic and political conditions of life. Forms and scope of social policy are determined by the specific circumstances of individual historical eras (Terziev, Petkova- Georgieva, 2019d-e). The study of social policy during the different periods of the human society creates opportunities for establishing the objective laws and conditions of development and changes in the social relations using modern methods and practices. Through social policy, the principles of humanity, as well as the protection and support of that part of the population living in a socially disadvantaged position, are upheld in accordance with generally accepted criteria and standards of living. The guidelines for the development of social policy determine the pace and nature of the reproduction of society at a higher level. At the core of social policy are such elements as social justice, social security, freedom of the human person, etc. The social policy in social and political terms can be seen as a unity of university discipline, scientific management and theory and practice of social work (Terziev, 2019c).

\section{REFERENCE LIST}

http://www.nsi.bg/, (2019).

http://seconomy.mlsp.government.bg/db/, (2019a).

Bozhilova, B. (2006). Byuletin №3, yuni 2006 g., MTSP (Б. Божилова, (Бюлетин №3, юни 2006 г., МТСП).

Terziev, V., Nichev, N., Simeonov, S. (2018). Teoretichni osnovi i modeli na osiguritelnite sistemi. // Sbornik dokladi ot nauchna konferentsiya „Aktualni problemi na sigurnostta” 25-26 oktomvri 2018 g., Nauchno napravlenie "Sotsialni i pravni aspekti na sigurnostta i otbranata”, NVU „Vasil Levski”, Veliko Tarnovo, Balgariya, 4, 2018, str. 138-145, ISSN 2367-7465 (Терзиев, В., Ничев, Н., Симеонов, С. Теоретични основи и модели на осигурителните системи. // Сборник доклади от научна конференция „Актуални проблеми на сигурността” 25-26 октомври 2018 г., Научно направление „Социални и правни аспекти на сигурността и отбраната”, НВУ „Васил Левски”, Велико Търново, България, 4, 2018, стр. 138-145, ISSN 2367-7465).

Terziev, V., Nichev, N., Simeonov, S. (2018a). Zdraveopazvaneto kato chast ot sistemite za sotsialna zashtita - sravnitelen analiz na razvitieto v stranite ot Evropeyskiya sayuz. // Sbornik dokladi ot nauchna konferentsiya „Aktualni problemi na sigurnostta” 25-26 oktomvri 2018 g., Nauchno napravlenie "Sotsialni i pravni aspekti na sigurnostta i otbranata”, NVU „Vasil Levski”, Veliko Tarnovo, Balgariya, 4, 2018, str. 146-159, ISSN 2367-7465 (Терзиев, В., Ничев, Н., Симеонов, С. Здравеопазването като част от системите за социална защита - сравнителен анализ на развитието в страните от Европейския съюз. // Сборник доклади от научна конференция „Актуални проблеми на сигурността” 25-26 октомври 2018 г., Научно направление „Социални и правни аспекти на сигурността и отбраната”, НВУ „Васил Левски”, Велико Търново, България, 4, 2018, стр. 146-159, ISSN 2367-7465).

Terziev, V., Nichev, N., Simeonov, S. (2018b). Istorichesko razvitie na pensionnoto osiguryavane na voennosluzheshtite v Balgariya. // Sbornik dokladi ot nauchna konferentsiya „Aktualni problemi na sigurnostta” 25-26 oktomvri 2018 g., Nauchno napravlenie „Sotsialni i pravni aspekti na sigurnostta i otbranata”, NVU „Vasil Levski”, Veliko Tarnovo, Balgariya, 4, 2018, str. 160-172, ISSN 2367-7465 (Терзиев, В., Ничев, Н., Симеонов, С. Историческо развитие на пенсионното осигуряване на военнослужещите в България. // Сборник доклади от научна конференция „Актуални проблеми на сигурността” 25-26 октомври 2018 г., Научно направление „Социални и правни аспекти на сигурността и отбраната”, НВУ „Васил Левски”, Велико Търново, България, 4, 2018, стр. 160172, ISSN 2367-7465).

Terziev, V., Banabakova, V., Georgiev, M. (2018c). Modern dimensions of social policies. // International journal scientific papers Vol 23.4 Promoted in Budva, Montenegro 24-27.05.2018, IKM - Skopje, 23, 2018, N 4, pp. 935-944, ISSN 1857-923X (for e-version) ISSN 2545- 4439 (for printed version).

Terziev, V., Banabakova, V., Georgiev, M. (2018d). Social support as part of social policy. // International journal scientific papers Vol 23.4 Promoted in Budva, Montenegro 24-27.05.2018, IKM - Skopje, 23, 2018, N 4, pp. 973-980, ISSN 1857-923X (for e-version) ISSN 2545 - 4439 (for printed version).

Petkova, S., (2019b). The Impact of Nanomaterials Usage on the Human Health and Nature Environment. // 
IJASOS- International E-Journal of Advances in Social Sciences, Vol. V, Issue 15, December 2019

Journal of Environmental Protection and Ecology, b.2(20), 2019, pp. 345 - 353, ISSN 1311-5065.

Petkova - Georgieva, S. (2018e). Contemporary Economic Analysis of The Bulgarian Health Care System Human Resources, Facilities and Establishments. // Mezhdunarodnayy nauchnayy zhurnal "Nauchnaye gorizontay", 12 (16), 2018, s. 93 - 99, ISSN 2587-618X (Petkova - Georgieva, S. Contemporary Economic Analysis of The Bulgarian Health Care System - Human Resources, Facilities and Establishments. // Международный научный журнал “Научные горизонты”, 12 (16), 2018, c. 93 - 99, ISSN 2587-618X).

Petkova - Georgieva, S., Yanakieva, A. (2018f). The Psychological Pressure Factors as a Part of Medical Ergonomics. // International Annual Edition of Applied Psychology: Theory, Research, and Practice, Saratov: Saratov State University, V.5 (1), 2018, pp. 21-28, ISSN 2313-4097.

Petkova - Georgieva, S. (2017). The Importance of the Conceptual Controlling Model in the Health and Care Management System Using as an Example the Management of a Hospital. // Annual of University "Prof. Dr. Assen Zlatarov", Burgas, Bulgaria, V. XLVI (2), 2017, pp. 109 - 114, ISSN 2603-3976.

Petkova - Georgieva, S. (2016). Nasoki za usavarshenstvane strukturiraneto na deynostite po zdraveopazvane. // International Scientific Conference "Management and Education", 23-24. 06, 2016, Burgas, Bulgaria, Volume II, 2016, str. 122-128, ISSN 13126121 (Петкова - Георгиева, С. Насоки за усъвършенстване структурирането на дейностите по здравеопазване. // International Scientific Conference "Management and Education", 23-24. 06, 2016, Burgas, Bulgaria, Volume II, 2016, стр. 122-128, ISSN 13126121).

Karadzhova, Z., Petkova - Georgieva, S. (2016a). Zdravniyat turizam v konteksta na natsionalnoto potreblenie. // Mezhdunarodna nauchna konferentsiya na tema: chlenstvoto na Balgariya $v$ Evropeyskiya sayuz: devet godini po-kasno, 7 oktomvri 2016, UNSS, Fakultet "Mezhdunarodna ikonomika i politika", Katedra "Mezhdunarodni ikonomicheski otnosheniya i biznes", Sofiya, str. 397 405, ISBN 978-954-644-976-4 (Караджова, 3., Петкова - Георгиева, С. Здравният туризъм в контекста на националното потребление. // Международна научна конференция на тема: членството на България в Европейския съюз: девет години по-късно, 7 октомври 2016, УНСС, Факултет "Международна икономика и политика", Катедра "Международни икономически отношения и бизнес", София, стр. 397 - 405, ISBN 978-954-644-976-4).

Petkova - Georgieva, S, Tasheva, Y. (2018g). Analysis of condition and possibilities for improving of financial management of healthcare in Bulgaria. // International Journal "Knowledge in practice", XIX-th International Scientific Conference, Vol. 28.1, Bansko, IKM - Skopje, 28, 2018, 1, pp. 309 - 314, ISSN 1857- 923X (for e-version), ISSN 2545 - 4439 (for printed version).

Terziev, Venelin. (2019c). Social efficiency as a measure of social activities. // Proceedings of SOCIOINT 2019- 6th International Conference on Education, Social Sciences and Humanities 24-26 June 2019Istanbul, Turkey, International Organization Center of Academic Research, Istanbul, Turkey, 2019, pp. 363-373, ISBN: 978-605-82433-6-1.

Terziev, V., Petkova- Georgieva, S. (2019d). The performance measurment system key indicators and the determinants impact on the level of decentralization using as an example a subdivisional unit from the Bulgarian social health and care experience. // Proceedings of SOCIOINT 2019- 6th International Conference on Education, Social Sciences and Humanities 24-26 June 2019- Istanbul, Turkey, International Organization Center of Academic Research, Istanbul, Turkey, 2019, pp. 515-524, ISBN: 978-605-82433-6-1.

Terziev, V., Petkova- Georgieva, S. (2019e). A research study of nonlinearity experiencing in the rate of current account deficit to the Bulgarian health and care national product. // Proceedings of SOCIOINT 2019- 6th International Conference on Education, Social Sciences and Humanities 24-26 June 2019Istanbul, Turkey, International Organization Center of Academic Research, Istanbul, Turkey, 2019, pp. 525-533, ISBN: 978-605-82433-6-1. 